\title{
Pendampingan Penggunaan Media Pembelajaran Berbasis Gamifikasi di Masa Pandemi COVID-19
}

\author{
Atsani Wulansari ${ }^{1}$, Arum Nisma Wulanjani2 ${ }^{2}$, Gilang Fadhilia Arvianti ${ }^{3}$, \\ Candradewi Wahyu Anggraini ${ }^{4}$, Endah Ratnaningsih ${ }^{5}$ \\ 1,2,3,4,5FKIP Universitas Tidar \\ e-mail: ${ }^{1}$ atsani_wulansari@untidar.ac.id, 2arum_nisma@untidar.ac.id, \\ 3gilangfadhilia@untidar.ac.id, ${ }^{4}$ candradewi@untidar.ac.id, \\ 5endahratna@untidar.ac.id,
}

\begin{abstract}
Abstrak
Tujuan dilakukan pengabdian ini adalah untuk memberikan pelatihan dan pendampingan penggunaan media pembelajaran daring selama program belajar dari rumah, dengan metode gamifikasi bagi para guru SD Purwodadi, Kabupaten Magelang. Hal ini dilakukan karena dari hasil kuesioner awal yang kami berikan menunjukkan bahwa sebagian besar guru di SD Negeri Purwodadi masih belum menggunakan media pembelajaran berbasis gamifikasi kepada anak didiknya. Pengabdian ini dilakukan dengan model pembelajaran bauran (blended learning) dengan menggabungkan pertemuan dan daring. Metode yang digunakan dalam pengabdian kepada masyarakat ini adalah observasi, perencanaan, pelaksanaan, dan evaluasi. Berdasarkan hasil kuesioner dan koordinasi tim pengabdian, pihak mitra diberikan materi mengenai quizlet dan quizizz. Pihak mitra juga diberikan proyek mandiri sebagai indikator pemahaman dan peningkatan ketrampilan terhadap media pembelajaran daring. Pihak mitra memberikan respon positif terhadap pendampingan ini dengan mencoba menggunakannya untuk pengajaran daring.
\end{abstract}

Kata Kunci: pembelajaran daring, gamifikasi, quizlet, quizizz

\begin{abstract}
The purpose of this community service is to provide training and assistance in the use of online learning media, which is called gamification, during study from home program for teachers at SD Purwodadi, Magelang Regency. The community service is needed to be performed because the results of the initial questionnaire showed that most of the teachers at SD Negeri Purwodadi have not use gamification-based learning media for their students yet. This community service is held with blended learning in which the method is combined online and offline. The method is observing, planning, implementing, and evaluating. The result of the questionnaire and coordination of the community service team, the teachers are given quizlet and quizizz material. The teachers also asked to do individual project as one of indicator of understanding and improvement skill toward online learning media. The teachers are giving positive respond with the new knowledge and tried to use this gamification as their method during study from home era.
\end{abstract}

Keywords: online teaching process, gamification, quizlet, quizziz 


\section{Pendahuluan}

Kemajuan teknologi dan informasi menuntut perubahan proses pembelajaran untuk membekali peserta didik menghadapi kompetensi yang mumpuni di masa depan. Peserta didik saat ini adalah Generasi Z atau Net Generation, yang mempunyai karakteristik berbeda dengan generasi terdahulu. Inovasi dalam pembelajaran pada generasi $\mathrm{Z}$ sangat diperlukan melihat karakteristik mereka yang cenderung memiliki gaya belajar aktif, sequential, sensing, dan visual (Wardoyo, 2013). Salah satu inovasi dalam pembelajaran adalah dengan membuat media pembelajaran yang menarik dan interaktif bagi siswa.

Media pembelajaran dapat digunakan untuk menjembatani komunikasi antara pengajar dan peserta didik. Selain itu, penggunaan media pembelajaran yang tepat dapat merangsang keaktifan peserta didik. Hal ini sesuai dengan Miarso dalam Kariman \& Mulia (2013) bahwa menggunakan media pembelajaran secara tepat dan bervariasi dapat mengatasi sikap pasif anak didik.

Oleh sebab itu, guru sebagai fasilitator di dalam kelas harus mampu membuat media pembelajaran yang menarik sehingga siswa mendapatkan pengalaman belajar yang menyenangkan. Selain itu, guru juga harus mempunyai kompetensi pedagogi yaitu kemampuan mengelola pembelajaran yang meliputi pemahaman terhadap peserta didik. Hal tersebut dapat membantu guru dalam merancang dan melaksanakan pembelajaran sesuai dengan karakteristik peserta didik.

Pandemi COVID - 19 telah mengubah pembelajaran tatap muka menjadi pembelajaran daring. Hal tersebut sangat berdampak dengan penggunaan teknologi dalam pembelajaran. Guru di setiap jenjang pendidikan diharapkan menguasai media pembelajaran daring untuk menunjang kelangsungan pembelajaran. Salah satu media pembelajaran daring yang dapat digunakan adalah media pembelajaran berbasis gamifikasi. Gamifikasi adalah penggunaan elemen-elemen game dalam pembelajaran (Jusuf, 2016; Takdir, 2017). Gamifikasi tersebut dapat digunakan untuk memberikan motivasi siswa dan memberikan suasana yang berbeda dalam kelas daring.

Hasil dari kuesioner menunjukkan bahwa sebagian besar guru di SD mitra belum menggunakan media pembelajaran daring. Para guru di SD mitra masih menggunakan fasilitas WA untuk kegiatan belajar dari rumah. Solusi yang ditawarkan dari permasalahan di atas adalah dengan memberikan pelatihan dan pendampingan bagi para guru untuk menggunakan media pembelajaran daring berbasis gamifikasi. Pendampingan ini dipilih dengan tujuan agar para guru mampu menggunakan media pembelajaran daring selama program belajar dari rumah.

Media pembelajaran dapat membantu guru dalam melaksanakan satu atau beberapa fungsi dalam pengajaran, seperti mengisahkan, mengontrol/mengecek, memberikan penguatan dan mengadakan evaluasi (Mahnun, 2012). Media pembelajaran dapat disesuaikan dengan kondisi siswa dengan mempertimbangkan soal biaya, ketersediaan peralatan, waktu ketersediaan aliran listrik, kualitas teknis ruang kelas, dan kemampuan guru menggunakan media secara tepat. Penelitian (Firmadani et al., 
2017) mengemukakan bahwa media pembelajaran mampu meningkatkan motivasi dan intelektual siswa. Dengan pelatihan ini diharapkan para guru di lingkungan UPTD kecamatan Tegalrejo khususnya SD Purwodadi mampu menggunakan media pembelajaran berbasis gamifikasi selama program belajar dari rumah.

\section{Metode}

Program pengabdian ini dilaksanakan di SD Negeri Purwodadi, Kecamatan Tegalrejo, Kabupaten Magelang. Peserta dalam kegiatan pengabdian ini adalah guru di SD tersebut berjumlah 9 orang. Pengabdian ini dilakukan dengan model pembelajaran bauran (blended learning) dengan menggabungkan pertemuan tatap mula dan daring (Wardani et al., 2018). Model tersebut dipilih karena pengabdian ini dilakukaan saat pandemic COVID-19.

Metode yang digunakan dalam pengabdian kepada masyarakat ini adalah observasi, perencanaan, pelaksanaan, dan evaluasi. Pertemuan tatap muka dilakukan saat observasi, pembukaan dan penutupan. Sedangkan untuk pelaksanaan, pelatihan dan pendampingan diberikan secara daring Whatsapp group. Tim pengabdian membuat video yang diunggah melalui youtube maupun google drive untuk memberikan penjelasan tentang penggunaan media pembelajaran berbasis gamifikasi. Kegiatan ini dilaksanakan pada tanggal 5 - 26 Oktober selama 7 kali pertemuan.

Untuk mengetahui tingkat efektivitas dan efisiensi program pengabdian, tim pengabdian beserta guru SD mitra melakukan evaluasi. Evaluasi ini merupakan refleksi dari semua kegiatan.

\section{Hasil dan Pembahasan}

\section{Pelaksanaan Program Pengabdian Kepada Masyarakat}

Kegiatan pengabdian ini diawali dengan melakukan observasi secara luring dan daring. Observasi secara luring dilakukan untuk mengetahui keadaan SD mitra. Observasi daring dilakukan dengan cara memberikan kuesioner melalui google form tentang penggunaan media pembelajaran selama program belajar dari rumah.

Perencanaan dilakukan setelah melakukan observasi. Beberapa langkah yang dilakukan dalam tahap ini adalah:

1. Koordinasi Internal

Koordinasi ini dilakukan dengan tim pengabdian (dosen) untuk membagi tugas dan menyiapkan kebutuhan pelatihan (materi, perlengkapan, akomodasi, administratif)

2. Koordinasi Eksternal

Koordinasi ini dilakukan dengan mitra untuk bekerjasama dalam perekrutan peserta, pelaksanaan pelatihan serta penyusunan konsep materi pendampingan. 


\section{Materi Kegiatan Pengabdian kepada Masyarakat}

Dari hasil observasi dan koordinasi, tim pengabdian kemudian menyusun materi sesuai dengan kondisi SD mitra. Materi yang diberikan selama pendampingan dan pelatihan adalah sebagai berikut:

a. Quizlet

Quizlet merupakan perangkat sederhana yang mudah digunakan serta inovatif yang dapat membantu peserta didik untuk belajar. Quizlet adalah aplikasi flashcard yang dapat digunakan untuk pembelajaran. Aplikasi tersebut dapat diunduh melalui laman https:/ / quizlet.com/. Flashcard dalam quizlet berbentuk digital dan dapat diakses melalui website atau melalui ponsel berbasis android (smartphone). Flashcard yang disuguhkan Quizlet memudahkan user untuk dapat berinteraksi, bekerja sama, dan berbagi flashcard dengan user lainnya. Flashcard dapat dibuat dari awal dengan cara menyunting kartu yang tersedia (Sari, 2019). Selain itu, siswa juga dapat bermain sambal belajar dengan menggunakan quizlet. Berikut adalah quizlet yang kami gunakan untuk program pengabdian.
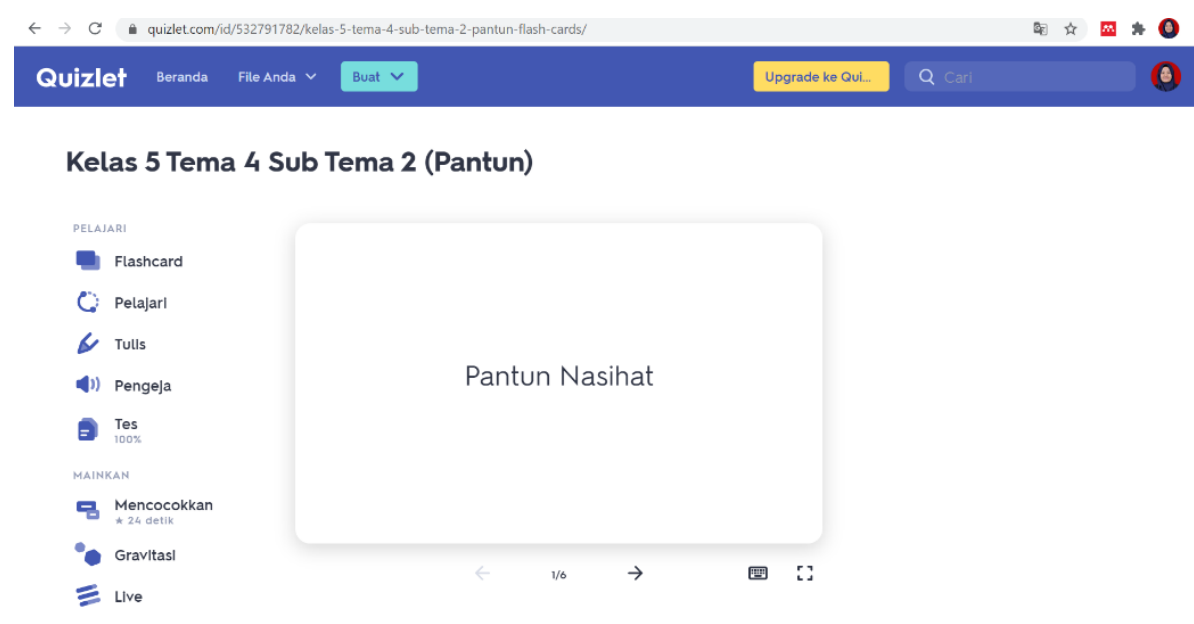

Gambar 1 Quizlet untuk pelatihan dan pendampingan (sumber: https:/ / quizlet.com/id/532791782/kelas-5-tema-4-sub-tema-2-pantun-flash-cards/)

b. Quizziz

Quizizz merupakan sebuah web untuk membuat permainan kuis interaktif yang bisa digunakan dalam pembelajaran di kelas. Quizziz juga dapat digunakan untuk evaluasi pembelajaran. Quizizz memiliki banyak fitur yang sama dengan Kahoot, tetapi menambahkan beberapa elemen lain. Quizizz dapat diatur dengan menggunakan timer atau mematikannya sehingga kuis juga dapat ditugaskan untuk siswa di luar kelas sebagai penilaian formatif. Hasil kuis dapat diunduh dalam bentuk file excel. 


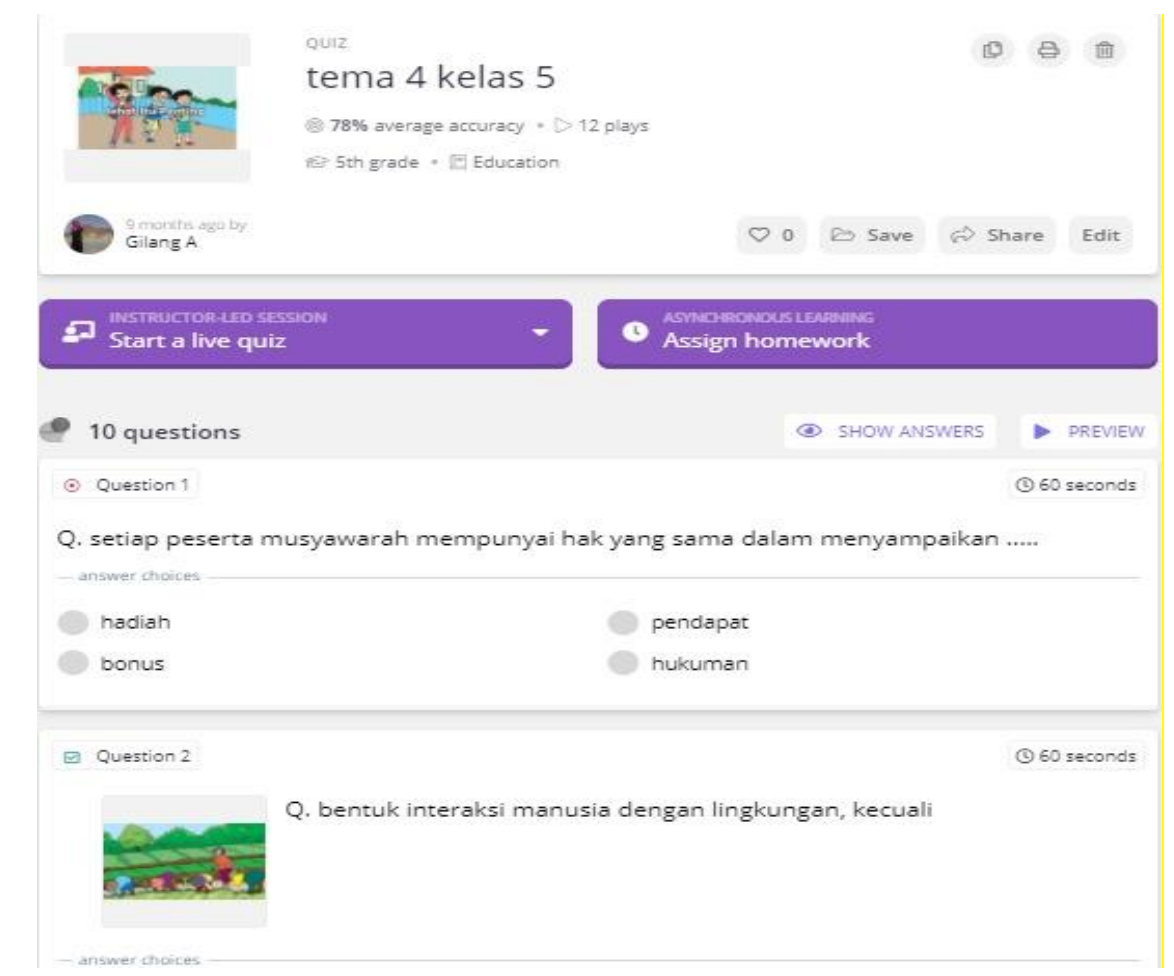

Gambar 2: Quizziz untuk pelatihan dan pendampingan (Sumber: https://quizizz.com/admin/quiz/5f866fe936191f001bd3f26a/tema-kelas)

Kedua materi di atas diberikan kepada pihak mitra selama program pelatihan melalui video yang diunggah melaui google drive dengan tautan berikut https:/ / drive.google.com/file/d/1okpxkDC7qKOU2AaEiPAgEh0TJZj8EHxc/view? usp=sharing dan juga melalui youtube dengan alamat https://youtu.be/pPwTucvyXTQ.

Pihak mitra tidak hanya diberikan pengetahuan-pengetahuan dasar terkait dengan media pembelajaran daring yang digunakan tetapi pihak mitra juga diberikan proyek mandiri sebagai indikator pemahaman dan peningkatan ketrampilan terhadap mediamedia pembelajaran daring.

Evaluasi program pengabdian ini dilakukan untuk mengetahui keefektifan program pendampingan. Secara umum, kegiatan ini berjalan dengan cukup lancar. Para guru dan juga kepala sekolah menyampaikan kendala yang mereka hadapi selama program pendampingan ini. Kendala yang dihadapi adalah terkait dengan waktu pelaksanaan yang singkat dan masih dalam pandemi COVID-19 sehingga kurang maksimal.

Setelah mengikuti program pendampingan ini, tim pengabdian melakukan wawancara kepada guru di SD mitra. Secara garis besar, para guru mengatakan bahwa program pendampingan ini sangat bermanfaat. Mereka mendapatkan tambahan media baru untuk diaplikasikan di kelas. Selain itu, para guru juga menyampaikan kesulitan yang mereka hadapi tentang penggunaan aplikasi tersebut. Para guru 
berpendapat bahwa mereka membutuhkan waktu yang lama untuk persiapan dan praktek.

Para guru juga mengatakan bahwa aplikasi quizlet dan quizziz bisa digunakan di kelas daring maupun luring. Oleh karena itu, aplikasi yang diajarkan oleh tim pengabdian akan digunakan selama dan setelah kegiatan belajar dari rumah.

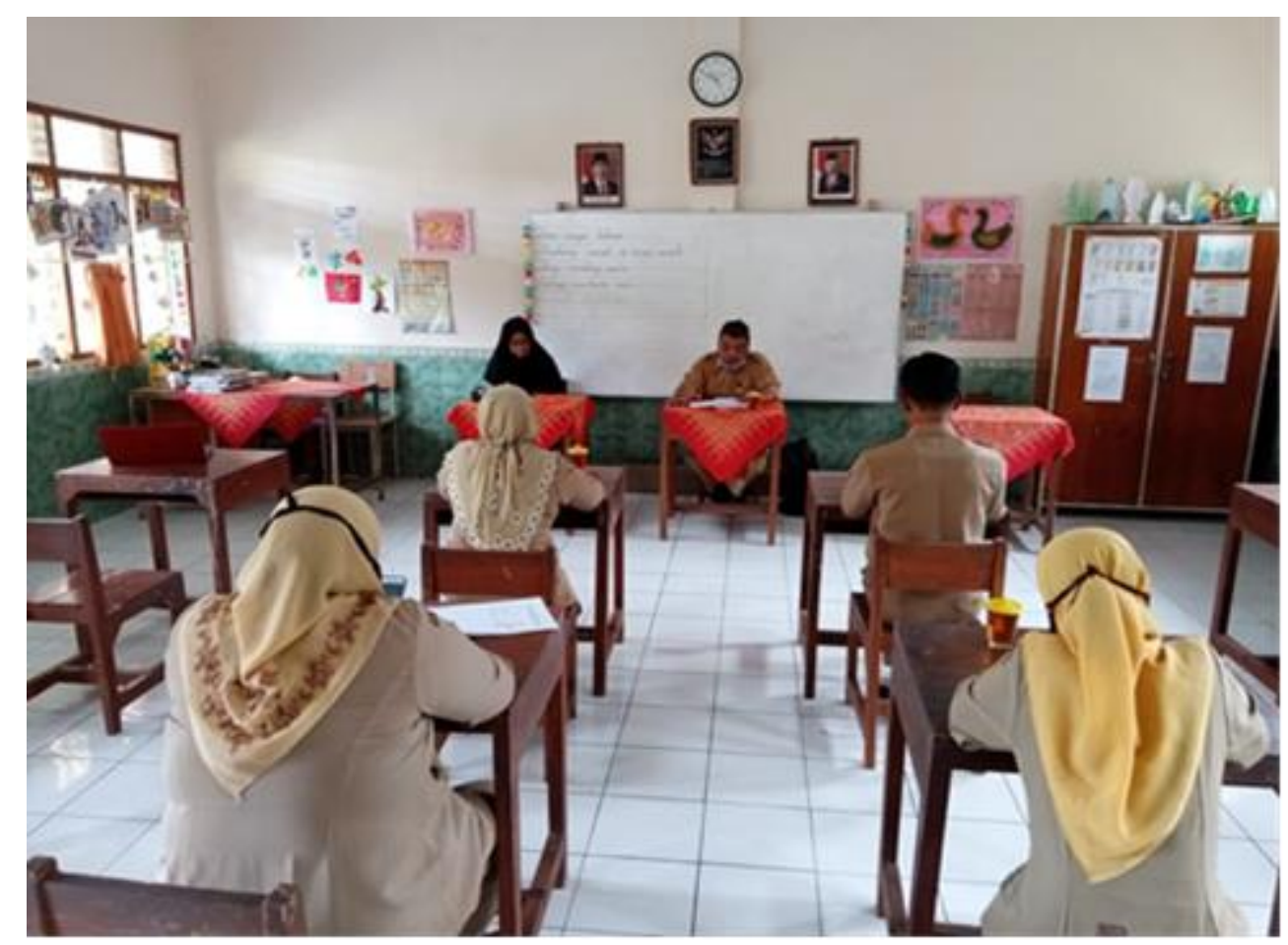

Gambar 3. Evaluasi dan penutupan program pendampingan

\section{Simpulan dan Rekomendasi}

Program pengabdian ini cukup sukses meskipun tim pengabdian menemui berbagai kendala karena pandemi COVID-19. Faktor pendukung dari cukup suksesnya kegiatan pendampingan ini adalah kerja sama antara tim pengabdian dan kepala sekolah di SD mitra dalam penyusunan materi dan jadwal. Di sisi lain, kebutuhan guru tentang media pembelajaran daring selama pandemi juga berperan penting dalam kelangsungan pendampingan. Namun, kegiatan yang dilakukan secara daring menurut guru di SD mitra kurang efektif karena kendala signal. Selain itu, beberapa guru juga tidak mengikuti kegiatan secara maksimal karena kesibukan untuk menyiapkan materi di kelas. Dari kegiatan pendampingan ini, diharapkan para guru dapat mengaplikasikan media pembelajaran quizlet atau quizziz kepada siswa di kelas daring. Lebih lanjut, para guru diharapkan mampu mengembangkan media pembelajaran daring sesuai dengan kondisi kelas. 


\section{Penghargaan}

Kami mengucapkan terima kasih kepada kepala sekolah dan guru SD Purwodadi yang bersedia menjadi mitra. Kami juga mngucapkan terima kasih kepada FKIP Universitas Tidar yang telah mendukung kegiatan ini.

\section{Daftar Pustaka}

Firmadani, F., Shalima, I., \& Al Firdaus, M. M. (2017). Pelatihan Pembuatan Media Pembelajaran Interaktif dengan Ispring Presenter bagi Guru MI AL ISLAM Balesari Kecamatan Windusari Kabupaten Magelang. Conference on Language and Language Teaching, 170-177.

Jusuf, H. (2016). Penggunaan Gamifikasi dalam Proses Pembelajaran. Jurnal TICOM, $5(1), 1-6$.

Kariman, T. M., \& Mulia, E. (2013). Pemanfaatan Weblog Sebagai Media Pembelajaran Untuk Meningkatkan Hasil Belajar Bahasa Inggris. Jurnal Teknologi Pendidikan (JTP), 5(1), 69-82. https:/ / doi.org/10.24114/jtp.v5i1.515

Mahnun, N. (2012). Media Pembelajaran (Kajian terhadap Langkah-langkah Pemilihan Media dan Implementasinya dalam Pembelajaran). An-Nida'Jurnal Pemikiran Islam, 37(1), 27-35.

Sari, D. E. (2019). Quizlet: Aplikasi Pembelajaran Berbasis Smartphone Era Generasi Milenial. Jurnal Pendidikan Ilmu Sosial, 29(1), 9-15. https://doi.org/10.23917/jpis.v29i1.8150

Takdir, M. (2017). Kepomath Go “ Penerapan Konsep Gamifikasi Dalam Pembelajaran Matematika Dalam Meningkatkan Motivasi Belajar Matematika Siswa ." Penelitian Pendidikan INSANI, 20, 1-6.

Wardani, D. N., Toenlioe, A. J. E., \& Wedi, A. (2018). Daya Tarik Pembelajaran Di Era 21 Dengan Blended Learning. Jurnal Kajian Teknologi Pendidikan (JKTP), 1(1), 1318.

Wardoyo, S. M. (2013). Pembelajaran Berbasis Riset. Akademia Permata. https://opac.perpusnas.go.id/DetailOpac.aspx?id=885086 (Accessed: 30 October 2020). 